\title{
STUDY ON THE EFFECT OF MUSIC THERAPY ON MIDDLE-AGED AND ELDERLY INDIVIDUALS WITH DEPRESSION
}

\author{
ESTUDO SOBRE O EFEITO DA TERAPIA MUSICAL SOBRE INDIVÍDUOS DE MEIA-IDADEEIDOSOS \\ COM DEPRESSÃO
}

Jin Yang ${ }^{1}$ (D)

(Public health Education)

1. Yantai Nanshan University, Yantai Shandong, 265706, China.

\section{Correspondence:}

wrpi2255@sina.com

\begin{abstract}
To explore the clinical effect of music therapy in the treatment of middle-aged and elderly patients with depression. From June 2019 to June 2020, 100 patients with depression in a community were selected as the object of this study, and were divided into a control group and an observation group according to the order of visits, with 50 patients in each group. There was no significant difference between the two groups in terms of gender, age, education level and drug treatment (medication dose, type) ( $P>0.05$ ). The patients in the control group were treated with conventional antidepressant drugs. The patients in the observation group added music therapy to the conventional therapy. The music therapist needs to fully understand the basic situation of the patient and formulate a suitable music treatment plan according to the actual state of the patient. Compare the HANA and PSP scores between the two groups of depressive patients after treatment to judge the treatment effect on the patients. The Hana and PSP scores in the observation group after treatment were significantly higher than those in the control group $(P<0.05)$. To treat depression, in addition to selecting appropriate drugs, alleviating the emotional state of patients is more important. Music therapy as an auxiliary treatment of traditional therapy, in the treatment of depression in the elderly, has been effectively verified, we should actively promote its application.
\end{abstract}

Keywords: Middle-aged and elderly; depression; music therapy; therapeutic effect.

\section{RESUMO}

Explorar o efeito clínico da terapia musical no tratamento de pacientes de meia-idade eidosos com depressão. Dejunho de 2019 ajunho de 2020, 100 pacientes com depressão foram selecionados como objeto desteestudo, eforam divididos em um grupo controlee um grupo de observação de acordo com a ordem de consultas, sendo 50 pacientes incluídos em cada grupo. Não houve diferença significativa entre os dois grupos em termos de gênero, idade, escolaridade e tratamento medicamentoso (dose, tipo de medicação) ( $P>0.05$ ). Os pacientes do grupo controle foram tratados com medicamentos antidepressivos convencionais. Os pacientes do grupo de observação adicionaram a terapia musical à terapia convencional. Oterapeuta musical precisa entender completamente a situação básica do paciente e formular um plano de tratamento musical adequado de acordo com o estado real do paciente. Comparar os escores HANA ePSP entreos dois grupos de pacientes com depressão após tratamento para avaliar o efeito terapêutico dos pacientes. Os escores Hana e PSP no grupo de observação após o tratamento foram significativamente superiores às do grupo controle $(P<0.05)$. Para o tratamento da depressão, além da seleção de medicamentos apropriados, oestado emocional dos pacientes émais importante. A terapia musical Como tratamento auxiliar da Terapia tradicional no tratamento da depressão nos idosos foi efetivamente verificada, portanto devemos promover ativamente sua aplicação.

Descritores: Mediana edad; depresión; terapia musical; efectos terapêuticos.

\section{RESUMEN}

Explorar el Efecto Clínico de la Musicoterapia en el Tratamiento de Pacientes de Mediana Edady Ancianos con Depresión. Desde junio de 2019 a junio de 2020, se seleccionaron 100 pacientes con depresión en una comunidad como objeto de este estudio, y se dividieron en un grupo de control y un grupo de observación según el orden de visitas, con 50 pacientes en cada grupo. No hubo diferencias significativas entre los dos grupos en términos de sexo, edad, nivel de educación y tratamiento farmacológico (dosis de medicación, tipo) (P>0,05). Los pacientes del grupo de control fueron tratados con fármacos antidepresivos convencionales. Los pacientes del grupo de observación agregaron la musicoterapia a la terapia convencional. El musicoterapeuta debe comprender completamentela situación básica del pacientey formular un plan de tratamiento musical adecuado de acuerdo con el estado real del paciente. Se compararon las puntuaciones de HANAY PSP entre los dos grupos de pacientes depresivos después del tratamiento para juzgar su efecto del tratamiento en los pacientes. Las puntuaciones de Hana y PSP en el grupo de observación después del tratamiento fueron significativamente más altas que las del grupo de control $(P<0,05)$. Para tratar la depresión, además de seleccionar los fármacos adecuados, es más importante aliviar el estado emocional de los pacientes. La musicoterapia como tratamiento auxiliar de la terapia tradicional, en el tratamiento de la depresión en el anciano, ha sido efectivamente comprobada, debemos promover activamente su aplicación.

Descriptores: Meia-idade e idosos; depressão; terapia musical; efeito terapêutico. 


\section{INTRODUCTION}

Depression is a common mental illness in modern society, mainly manifested as low mood, decreased interest, pessimism, slow thinking, lack of initiative, self-blame, poor diet, sleep, worry about suffering from various diseases, and feel more body Discomfort, severe cases may appear suicidal thoughts and behavior. Among middle-aged and elderly people, the incidence of depression is higher. The patient is nervous, anxious, depressed, and uncomfortable all over the body, waking up early, panicking all day long, having a sense of catastrophe, often sighing, blaming himself, and even refusing to eat. Music therapy is used by professional music therapists to use music and the physical, emotional, spiritual, social, and aesthetic factors contained in it to help people improve their health. It is one of the auxiliary therapies for health treatment. Depression is an affective disorder with depressed mood and decreased interest as the core symptoms. Its occurrence and development always run through inner conflicts, depression, and anxiety. Music is one of the most important and charming areas in human spiritual life. It accompanies the entire historical process of human beings and penetrates into all aspects of social life. It produces and continues to play a huge role that cannot be ignored. ${ }^{1}$ Music therapy can directly act on the emotional centers of the human brain such as the hypothalamus and limbic system through hearing to produce a guiding role in regulating the patient's mental state and alleviating depression and anxiety.

Music is the product of human psychological activity, and the ways and means by which music realizes its various social functions are mainly audio experience, emotional feeling, imagination and intuition and other psychological activities. During a survey of 200 cancer patients, Yaman Akta Y found that 127 of them had experienced strong mental stimulation before the onset of the disease and developed emotional disorders. Azoulay R found that the incidence of coronary heart disease among widowed men was significantly higher than that of the general population, and the suicide rate was also significantly higher. ${ }^{2}$ Physiologist Carlos Antonio did a lot of research in the early 20th century and showed that anxiety and depression can inhibit gastrointestinal motility and the secretion of digestive glands, resulting in decreased appetite, increased heart rate, increased blood pressure, and increased blood sugar. ${ }^{3}$ Some serious diseases such as myocardial infarction, hypertension, and cancer are also related to bad mood. Music therapy usually requires the combination of clinical therapy, psychotherapy, bio musicology, music acoustics, music theory, psychoacoustics, music cognition, music aesthetic feeling integration and comparative musicology. ${ }^{4}$ Music therapy can improve people's quality of life, promote people's physical and mental health, and plays an increasingly important role in rehabilitation medicine. It is especially applied to patients who are more fond of or good at music, because they are sensitive to music and easy to resonate.

Music therapy is a comprehensive new discipline integrating psychology, medicine, physiology, philosophy, music and art. As an applied science, it is gradually accepted by the society and is becoming more and more mature. ${ }^{5}$ As one of the important social and cultural phenomena, music can play an important role in health and has therapeutic effect. Psychomusicotherapy is to use the principle of psychotherapy to achieve the purpose of treating diseases through musical means. As a non-invasive treatment method, more and more people pay attention to it, and the therapeutic effect of music therapy on depression is also gradually concerned by people. Music therapy is a new way to treat depression. With the deepening of medical research and the popularization of clinical application, music therapy has been gradually accepted. There are many treatment methods for middle-aged and elderly depression, and music therapy is especially effective. Music therapy can be achieved through targeted appreciation, singing, playing, learning a certain musical instrument, and communicating with therapists. ${ }^{6}$ Through careful selection of music, patients can change from uncomfortable and unhealthy physiological and psychological state to comfortable state. From June 2019 to June 2020, 100 cases of elderly patients with depression were selected as the research object to explore the clinical effect of music therapy in the treatment process of middle-aged and elderly patients with depression.

\section{HANA score of two groups of patients with depression after treatment}

The HAMA score of the patients in the observation group after treatment was significantly higher than that of the control group. The difference was statistically significant $(P<0.05)$. The score statistics are shown in Table 1.

\section{PSP scores of two groups of depression patients after treatment}

The PSP score of depression patients in the observation group was significantly higher than that of the control group after treatment. The difference was statistically significant $(P<0.05)$. The score statistics are shown in Table 2.

With the quickening pace of life and increasing social pressure, depression is on the rise in recent years. Music therapists exist in almost every professional field that needs help, such as hospitals, cancer centers, schools, alcohol and drug rehabilitation centers, mental hospitals, prisons and so on. Here, we mainly discuss the application of music therapy in middle-aged and elderly depression. Due to various social reasons and self-rejection, the treatment compliance rate of patients with depression is only 50\%, and the other part is partial compliance or rejection, which brings heavy burden to society and family, and greatly increases the risk of suicide and self-harm, and even causes irreparable serious consequences. Music is a kind of special information which is similar to and different from language and other sounds, and can produce good physiological effects on various systems of human body. Music is special information which is similar to and different from language and other sounds. It can produce good physiological effects on every system of human body and eliminate the tension caused by various factors. In the process of music therapy, it is necessary to choose the appropriate music type. Easy and soothing music can drive patients' mood changes and help them relax. Passionate music can stimulate the emotional strength of patients, stimulate their confidence in life, and cultivate their positive living conditions. Choosing the right music to stimulate physiological and psychological changes should pay attention to the rhythm, tune and chorus of the music to affect the emotional state, such as soothing and stable rhythm has a relaxing and calming effect. Studies of modern neurophysiology have shown that the limbic system and the brainstem network structure in the nervous system play a major role in regulating the organs and body functions of the human body.

Table 1. HAMA scores of two groups of depression patients after treatment.

\begin{tabular}{c|c|c}
\hline Group & Number of cases & HAMA \\
\hline Observation group & 50 & $7.31 \pm 4.84$ \\
\hline Control group & 50 & $15.27 \pm 5.59$ \\
\hline $\mathrm{t}$ & & 5.994 \\
\hline $\mathrm{P}$ & & 0.000 \\
\hline
\end{tabular}

Table 2. PSP scores of two groups of depression patients after treatment.

\begin{tabular}{c|c|c}
\hline Group & Number of cases & PSP \\
\hline Observation group & 50 & $88.02 \pm 8.69$ \\
\hline Control group & 50 & $65.21 \pm 5.81$ \\
\hline $\mathrm{t}$ & & 11.981 \\
\hline $\mathrm{P}$ & & 0.000 \\
\hline
\end{tabular}


For human beings, at all levels of emotional intensity, it is important to learn to experience emotions deeply while not having to resort to them. People can learn to express sadness, frustration and anger through music experience to express joy and love. When the auditory sense of the patient listening to the music obtains this acoustic information, the information stabs the brain nerves, causing a series of physiological effects. Through music therapy, the patient can be restored to normal emotional emotions, which is conducive to the rehabilitation of the disease. Music is special information that is similar to and different from language and other sounds. It can produce good physiological effects on various systems of the human body, can eliminate tension and depression caused by various factors, improve stress ability, and stimulate patients to a better life. Longing and love. Music can increase the excitability of cortical nerves, activate and improve emotional state, eliminate the "stress state" caused by external mental and psychological factors, and improve stress ability. During the course of treatment, the patients in the treatment group seldom stayed in bed, which alleviated their anxiety and fear of hospitalization, and actively cooperated with medical staff to facilitate the management of the ward. An effective way to maintain emotional balance is to show that music can meet people's needs and provide a way for people to vent their emotions, which can affect people's emotions and calm them down.

As an art of emotion, music is the most important subject in aesthetic education, so it should play a unique role in the field of psychological education. Music is an art produced by the communication between people, and it is also a tool for communication between people. Like other arts, music is closely related to real life. It can create artistic images through organized music to express people's thoughts and feelings.
Music therapy is closely related to psychology. In all music activities, music therapy can reflect psychological characteristics. In the process of appreciating music, we need not only rich imagination and deep understanding, but also conscious image association such as contrast and foil. Music is the expression of the most natural nature of human thought and emotion. The feeling, experience and understanding of music is one of the basic ways of human survival and growth. Music, as the common spiritual food of human beings, can make people obtain pleasure and beauty in spirit. The regulation of emotion can make people eliminate excessive tension, guide their behavior to the correct and reasonable track, and promote the healthy development of psychology. As a social non-verbal communication art form, music can use invisible emotional penetration to reconcile the relationship between people, between people and society, between people and nature.

\section{CONCLUSIONS}

As a music therapist in psychiatry, one should not only master the professional knowledge of psychiatry, but also have good music literacy and understanding, so as to observe the illness and experience the patient's feelings. In addition to selecting suitable drugs for the treatment of depression, it is more important to relieve the emotional state of patients fundamentally. Music therapy, as an auxiliary treatment method of traditional therapy, has been effectively verified in the treatment of depression in middle-aged and elderly people, and we should actively promote its wide application.

The author declare no potential conflict of interest related to this article

AUTHORS' CONTRIBUTIONS: The author has completed the writing of the article or the critical review of its knowledge content. This paper can be used as the final draft of the manuscript. Every author has made an important contribution to this manuscript. Jin Yang: writing and execution.

\section{REFERENCES}

1. Ram H, Dastager SG. Re-purposing is needed for beneficial bugs, not for the drugs. Int Microbiol. 2019; 22(1):1-6.

2. Canga B, Azoulay R, Raskin J, Loewy J. AIR: Advances in Respiration - Music therapy in the treatment of chronic pulmonary disease. Respiratory Medicine. 2015; 109(12):1532-1539.

3. Dóro CA, Zanis JN, Cunha R, Dóro MP. Music therapy improves the mood of patients undergoing hematopoietic stem cells transplantation (controlled randomized study). Supportive Care in Cancer. 2017; 25(3):1013-1018
4. Bratman GN, Hamilton JP, Hahn KS, Daily GC, Gross JJ. Nature experience reduces rumination and subgenual prefrontal cortex activation. Proc Natl Acad Sci U S A. 2015; 112(28):8567-72.

5. Chirico A, Maiorano P, Indovina P, Carla Milanese, Giordano GG, Alivernini F, G, et al. Virtual reality and music therapy as distraction interventions to alleviate anxiety and improve mood states in breast cancer patients during chemotherapy. J Cell Physiol. 2020; 23(6):5353-5362.

6. Cunningham JEA, Shapiro CM. Cognitive Behavioural Therapy for Insomnia (CBT-I) to treat depression: A systematic review. Journal of Psychosomatic Research. 2018; 106(1):1-12. 